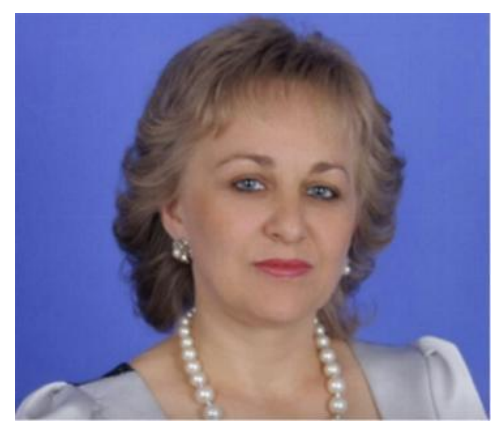

\author{
Неля Сірант, \\ (м. Львів, Україна) \\ Nelia Sirant, \\ assistant of the Department of Elementary \\ and Pre-school Education, \\ Ivan Franko Lviv National University \\ (Lviv , Ukraine) \\ nelya03@ukr.net \\ ORCID ID: 0000-0345-1457-0630
}

асистент кафедри початкової та дошкільної освіти, Львівський національний університет імені Івана Франка

УДК 37.035.6(477)

\title{
ДИТИНА ЯК СУБ'ЄКТ ЕСТЕТИЧНОГО ВИХОВАННЯ В КОНТЕКСТІ ВИКЛИКІВ СЬОГОДЕННЯ
}

\begin{abstract}
Анотація. Стаття присвячена висвітленню проблеми естетичного виховання особистості дитини в контексті викликів сьогодення. Автор зазначає, що нині проблема естетичного виховання особистості набуває особливого значення, оскільки загострюються суспільні суперечності, втрачаються загальнолюдські цінності, життєві ідеали дітей та юнацтва. 3 погляду психології та педагогіки естетичне виховання $€$ актуальною, проте все ж недостатньо дослідженою проблемою. Неупереджений аналіз засвідчує, що погляди вчених на цю важливу проблему неоднозначні, тому утворюють мозаїчну картину на рівні теоретико-емпіричних міркувань.

Мета статті полягає в аналізі теорії естетичного виховання зростаючої особистості, узагальненні психолого-педагогічної та науково-методичної літератури з проблеми, визначенні теоретико-методичних засад дослідження, виокремленні ефективних умов естетичного виховання дітей. Під час роботи над публікацією використано метод історико-педагогічної ретроспективи для з'ясування еволюції поглядів науковців, педагогів на проблему естетичного виховання школярів, теоретичного аналізу, синтезу та узагальнення для виокремлення ефективних умов естетичного виховання зростаючого покоління.

Проаналізовано елементи естетичної культури як важливого складника всебічного розвитку особистості. Доведено, що

характер і ступінь розвитку естетичного почуття і естетичного смаку, їх виховання є важливим

чинником формування естетичної культури особистості. Автором відзначено, що проблема виховання естетичної культури школярів є надзвичайно актуальною і необхідною для подальшого вивчення та наукового обґрунтування.
\end{abstract}

Ключові слова: дитина, естетичне виховання, творча діяльність, естетичний ідеал, естетичний смак, естетичні почуття.

\section{CHILD AS A SUBJECT OF AESTHETIC EDUCATION IN THE CONTEXT OF TODAY'S CHALLENGES}

Abstract. The article reflects the content of aesthetic education and the peculiarities of the education of the aesthetic culture of pupils of a general educational institution. The elements of aesthetic culture as an important component of the all-round development of the individual are analyzed. It is also proved that the nature and degree of development of aesthetic sense and aesthetic taste, their upbringing is an important factor in the formation of the aesthetic culture of the individual. The author noted that the problem of educating the aesthetic culture of schoolchildren is extremely relevant and necessary for further study and scientific justification.

Aesthetic education forms understanding of beauty, aesthetic taste and high aesthetic ideals develops the need to keep beautiful. Aesthetics reveals the nature of the aesthetic in life and art learns the basic principles of aesthetic development of the world, explores the aesthetic laws of personality. Different assessments, tastes, views form the aesthetic sense. With the aesthetic ideas and ideals, they are the subjective aspect of aesthetic development of the world and make aesthetic consciousness of personality. It is a subjective reflection of the objective world and at the same time it is a way of essence aspect of real world cognition - its beauty.

While revealing the structure and function of aesthetic consciousness, aesthetics determines the formation of aesthetic feelings, evaluations, tastes, ideals. Creation of aesthetic conditions provides pedagogical activity of subjects and objects of education process in terms of aesthetics requirements.

The most general regularity of aesthetic education is natural pedagogical process dependence on the requirements of modern information society. Aesthetic education in the information society naturally depends on a combination of objective and subjective environmental factors that promote or inhibit the development of personality. Unity and interconnection of education and pers onal development are the regularities of aesthetic education process. Interconnection of regularities (laws) and principles is diffic ult.

Understanding the nature of principles allows consciously and creatively solve problems of education, organize educational activities, reasonably implement it and confidently reach the goal of education. It is established that only aesthetically and morally rich generation will be able to develop a strong state and change the stereotypes of behavior in modern society.

Keywords: child, aesthetic education, aesthetic culture, aesthetic needs, aesthetic ideals, aesthetic tastes. 


\section{ВСТУП}

Постановка проблеми. За сучасних умов модернізації української системи освіти пріоритетним завданням освітньої політики є організація цілісного науково обґрунтованого виховного процесу, орієнтованого на загальнолюдські цінності - формування творчої, діяльної, інтелектуально розвинутої й духовно багатої особистості. Нині проблема естетичного виховання особистості набуває особливого значення, оскільки загострюються суспільні суперечності, втрачаються загальнолюдські цінності, життєві ідеали дітей та юнацтва.

3 погляду психології та педагогіки естетичне виховання $€$ актуальною, проте все ж недостатньо дослідженою проблемою. Неупереджений аналіз засвідчує, що погляди вчених на цю важливу проблему неоднозначні, тому утворюють мозаїчну картину на рівні теоретико-емпіричних міркувань.

Аналіз останніх досліджень і публікацій. Водночас вивчення наукової літератури уможливлює виокремлення загального кола проблем, які потрапили до сфери інтересів учених (Д. Джола, І. Зязюн, Н. Калашник, Н. Киященко, О. Колесник, А. Ліндберг, Б. Лихачов, Б. Неменський, Г. Падалка, В. Сухомлинський та ін.) як найбільш важливі для дослідження проблеми естетичного виховання зростаючого покоління. Це зокрема: змістовна сутність естетичного виховання; розгляд компонентів, що входять до його структури; термінологічна відмінність естетичних понять і категорій; вплив різних видів, жанрів і напрямів мистецтва на естетичну вихованість особистості; мета, завдання і функції естетичного виховання, умови і методичні аспекти його розвитку; діагностика рівнів сформованості естетичної вихованості тощо. Хоча нами не передбачається глибокого аналізу кожного з окреслених питань, однак для визначення конкретної лінії вивчення специфіки естетичного виховання дитини необхідна певна орієнтація в цих проблемах.

META I ЗАВДАННЯ ДОсЛІДЖЕННЯ. Мета статті полягає в аналізі теорії естетичного виховання зростаючої особистості, узагальненні психолого-педагогічної та науково-методичної літератури з проблеми, визначенні теоретико-методичних засад дослідження, виокремленні ефективних умов естетичного виховання дітей.

МЕТОДИ ДОсЛІДЖЕННЯ: під час роботи над публікацією використовувалися метод історико-педагогічної ретроспективи для з'ясування еволюції поглядів науковців, педагогів на проблему естетичного виховання школярів, теоретичного аналізу, синтезу та узагальнення для виокремлення ефективних умов естетичного виховання зростаючого покоління.

\section{РЕЗУЛЬТАТИ ДОСЛІДЖЕННЯ}

Виклад основного матеріалу. Загальноприйнятим є положення про те, що естетичні властивості особистості не $€$ вродженими, а починають розвиватися у ранньому віці та залежать від особливостей соціального ареалу. Розвиток естетичного сприйняття дитиною дійсності та мистецтва відбувається перманентно як некерований, спонтанний процес у сім'ї та школі, навчанні й повсякденних домашніх справах, спілкуванні з природою та мистецтвом, через міжособистісні контакти з батьками, вихователями, вчителями тощо. Дитина зіштовхується з естетичними явищами і певним чином естетично «трансформується», однак при цьому естетична сутність предметів нею часто не усвідомлюється, а тривалий некоординований зовнішній вплив може сприяти формуванню викривленої перцепції цінностей, ідеалів та життя загалом. Тому загальновизнано, що цілеспрямований педагогічний естетико-виховний вплив, прилучення дітей до різноманітної художньо-творчої діяльності здатні розвинути їхню сенсорну сферу, забезпечити глибоке розуміння естетичних явищ, підняти до розуміння справжнього мистецтва, краси навколишньої дійсності та прекрасного в людській особистості. Зазначене вище підкреслює провідну роль цілеспрямованої педагогічної дії на естетичне становлення дитини.

Термін «естетичне виховання» здебільшого використовують синонімічно з художньою, музичною, театральною освітою, проте естетичне виховання $€$ ширшим поняттям, яке передбачає «виховання в людини гуманістичних якостей, інтересів і любові до життя в його різноманітних проявах» [3, с. 119].

Вітчизняна психолого-педагогічна наука в широкому сенсі під естетичним вихованням розуміє, по-перше, розвиток здатності дитини сприймати, відчувати, розуміти красу в житті та мистецтві, по-друге, виховання прагнення самому брати участь у перетворенні навколишнього світу «за законами краси», по-третє, систему залучення дітей до художньої діяльності з метою формування творчих художніх здібностей (В. Бутенко [1], Л. Виготський [2], Д. Джола [4], І. Зязюн [5], В. Кудін [6], Б. Лихачов [7], О. Отич [9], В. Сухомлинський [10] та ін.). Проведений аналіз психологопедагогічної літератури дав змогу виокремити ефективні умови естетичного виховання дітей: 1) створення позитивного емоційного клімату в сім'ї, закладі освіти, спрямованого на розвиток діалогу культур у процесі художньоестетичної діяльності; 2) урахування здібностей кожної дитини, індивідуальних і вікових особливостей при доборі художніх творів (літературних, музичних, образотворчих, декоративно-ужиткових тощо) та видів художньо-естетичної діяльності; 3) індивідуальний підхід як підґрунтя творчої художньо-естетичної діяльності; 4) тісна співпраця сім"ї та закладу освіти у річищі діалогу культур; 5) створення художнього середовища вдома та закладі освіти 3 максимальним використанням продуктів дитячої художньої творчості; 6) широке використання спонукальних методів для активізації художньо-естетичної діяльності, передовсім ігрових.

Практикою доведено, що естетичне виховання здійснюється на всіх етапах вікового розвитку особистості, проте чим раніше дитина потрапляє у сферу цілеспрямованого естетичного впливу, тим вищою буде його результативність. Змалечку (здебільшого через ігрову діяльність) дитина долучається до пізнання довкілля, через наслідування оволодіває елементами культури дій та спілкування з іншими. Гра - первинний і вельми продуктивний спосіб пробудження творчих потенцій, розвитку в дитини уяви та накопичення перших естетичних вражень. 3 цього приводу В. Сухомлинський переконливо зазначав: «Без емоційно-естетичного струменя неможливий повноцінний розумовий розвиток дитини... Краса й жива думка так само органічно поєднані, як сонце і квіти» [10, с. 43]. Досвід спілкування та діяльності спочатку формує у дітей елементарне, а згодом більш цілісне й адекватне розуміння прекрасного у мистецтві та довкіллі. 
Щодо проблеми естетичного виховання, то нині центральний конфлікт виник між тими, хто вбачає його метою навчання змісту мистецтва, та тими, хто розуміє його як процес самовираження. Сучасні науковці розглядають естетичне виховання у контексті «дилеми між навчальною та харизматичною позиціями», сформульованої шведською дослідницею А. Ліндберг. Перша позиція ґрунтується на переконанні, що здатність до оцінки мистецтва залежить від знань, а учень розглядається як «посуд», який можна ними наповнити; таким чином відбувається процес «об'єктифікації» учня. 3 іншого боку, полярна за своїм контекстом, «харизматична позиція» утверджує «суб'єктифікацію» учня, де здатність до оцінки та творення виходить зсередини, де вільне самовираження є способом індивідуального розвитку [13, с. 346]. Проте обидва підходи насправді не є кардинально протилежними: хоча А. Ліндберг називає один з них «об'єктивуючим» і «пасивним», його кінцевим результатом є здатність до самостійної оцінки мистецтва, результатом «суб'єктивуючого» й «активного» підходів є творча самореалізація, а об'єднуючим чинником виступає моральна стійкість індивіда.

Підґрунтям, на яке спирається система естетичного виховання, є мистецтво - музика, архітектура, скульптура, живопис, кіно, театр та інші види художньо-естетичної творчості. Ці платонівські і гегелівські ідеї дозволили сформулювати аксіому, згідно з якою мистецтво $є$ головним змістом естетики як науки, а краса - детермінуючим естетичним явищем. Мистецтво володіє необмеженим потенціалом для розвитку особистості, яка є центральним структурним елементом системи естетичного виховання, адже його мета, завдання та специфічні методи орієнтовані на естетичний і загальний розвиток особистості, збагачення її в педагогічному процесі з урахуванням індивідуальних і психологічних особливостей організації впливу на дітей різного віку. Мистецтво було і залишається головним предметом естетики, а художнє виховання - основним засобом фрормування естетичного ставлення до світу [7, с. 330].

Наріжною підсистемою, важливим чинником і первинним середовищем естетичного виховання $є$ сім'я, в якій батьки сприяють прилученню дитини до краси і творчості. Іншою ключовою підсистемою естетичного виховання $€$ освітній процес у школі, складовими та взаємодоповнювальними елементами якого є предмети природничоматематичного, гуманітарного й естетичного циклів, а також трудове навчання і виховання, а керівну роль у забезпеченні педагогічної спрямованості та доцільності цього процесу відіграє вчитель. Наступна підсистема позакласна і позашкільна діяльність дітей, пов'язана з навчально-виховною діяльністю в різних видах мистецтва; вона включає факультативні курси, гуртки, студії 3 предметів художньо-естетичного спрямування тощо. Функціонування цієї підсистеми передбачає необхідність використання творчого підходу до будь-якого виду діяльності дитини, індивідуальних форм і методів активізації ії інтересу до творчості, а також здійснення педагогічного контролю за соціально-цінною діяльністю дітей у процесі позакласної та позашкільної роботи, організації дозвілля дітей різного віку. Невід'ємним складником естетичного виховання дитини є самоосвіта і самовиховання, зорієнтовані на вдосконалення якостей особистості, яка реалізується через індивідуальні захоплення та сприяє активізації конструктивних здібностей: індивідуальної експресії, інтуїтивного мислення, творчої уяви, подолання стереотипів тощо.

Важливою підсистемою естетичного виховання є художньо-естетичний вплив засобів масової інформації, таких як преса, радіо, телебачення i, зокрема, Інтернету. Щодо останнього, то нині - це найдинамічніше середовище інформаційного обміну в історії людства. Статистика свідчить, що понад 2 мільярди людей $(26,1$

\% усього населення планети) користується ресурсами Інтернету; завдяки глобальній мережі за останні 5 років було створено і передано більше інформації, ніж за останні 50 років [15].

Комп'ютери й інформаційні системи знаходять застосування у нових галузях людської практики, впливаючи на психічні процеси і реорганізуючи не лише окремі дії, а й людську діяльність загалом. Застосування комп'ютерних мереж призводить до структурних і фрункціональних змін у психологічній діяльності людини, які торкаються пізнавальної, комунікативної й особистісної сфери, трансформують виконавчу здатність, процеси формування мотивації, потреб та інші важливі процеси діяльності людини. Парадоксально, але зростання кількості технологічних взаємозв'язків веде до інтенсифікації фрізичної й емоційної ізоляції людини, саме тому на сучасному етапі розвитку естетичне виховання повинно бути спрямованим передовсім на фрормування адекватного сприйняття людиною себе, тих, хто її оточує, і реальності.

Контроль з боку батьків і закладів освіти за діяльністю всіх зазначених елементів виявляється у вивченні й аналізі впливів, ступеня сорормованості в дітей естетичного ідеалу, смаку, критичної оцінки естетичної інформації, художніх інтересів і потреб школярів у галузі мистецтв, мотивів спілкування з ним. Таким чином, функціонування системи естетичного виховання школярів буде ефективним, якщо вона діятиме не ізольовано, а буде органічно вплетена у комплекс усієї навчально-виховної роботи та здійснюватиметься $з$ допомогою цілеспрямованого педагогічного керівництва.

Основою, на якій здійснюється естетичне виховання дитини, є певний рівень художньо-естетичної культури, її здатність до естетичного освоєння дійсності. Цей рівень виявляється як у розвитку всіх компонентів естетичної свідомості (почуттів, поглядів, переживань, оцінок, смаків, потреб та ідеалів), так і формуванні вмінь та навичок активної перетворювальної діяльності в мистецтві, праці, побуті, міжособистісних взаєминах. Формування в дітей певної системи художніх уявлень, поглядів, які зможуть допомогти їм виробити дієві критерії естетичних цінностей, готовність й уміння вносити елементи прекрасного у власне життя, розпочинається зі сприймання оточуючого, зокрема мистецтва.

Професор Т. Брамельд, головний ідеолог фрілософії освіти, відомої як реконструкціонізм, особливо наголошував на важливій ролі мистецтва й естетики в освіті та потребі вивчення проблем естетики у соціокультурному та соціополітичному контекстах. Те, що цей учений називав «соціальною самореалізацією», є всеосяжною цінністю в освіті, адже людський досвід $€$ «одночасно соціально й індивідуально спрямований. 
Мистецтво включено в цю концепцію як центральний елемент, адже воно є унікальним, органічним, синкретичним явищем, яке осягається індивідами та групами, включає поезію, живопис, скульптуру, танець, архітектуру і навіть ремісничі вироби щоденного вжитку» [11, с. 321].

Однак завданням естетичного виховання $€$ не лише розширення художнього сприймання, переліку прочитаних книг, почутих музичних творів, набуття досвіду перцепції й оцінки, а й організація почуттів, духовного зростання особистості, регуляція і корекція поведінки. За словами дослідника М. Гріні, завдяки естетичному вихованню «людський досвід поповнюється новими структурами, у ньому формуються нові моделі та відкриваються нові перспективи. Люди бачать інакше та по-іншому «резонують», адже твір мистецтва, «сприйнятий правильно у своїй повноті, ставить перед споглядачами вимогу, вимогу по-новому бачити, чути та ставати тими, ким раніше вони не були» [12, с. 392]. Саме спонукання до змін, на думку М. Гріні, є центральним завданням естетичного виховання дітей.

Естетичне виховання гармонізує та розвиває духовні здібності дитини, воно тісно пов'язане з моральним вихованням, оскільки краса виступає своєрідним регулятором людських взаємин, а завдяки красі людина часто інтуїтивно тягнеться і до добра. Естетичне виховання, залучення дитини до скарбниці світової культури

і мистецтва - необхідна умова для досягнення головної мети естетичного виховання - фрормування цілісної особистості, творчо розвиненої індивідуальності, що живе та діє «за законами краси».

Сучасне життя з його надмірними перевантаженнями, агресивним способом подання інформації та гіпертрофією інтелекту, що стала продуктом науково-технічного розвитку суспільства і характерна для багатьох сфер діяльності, зумовлює редукцію багатьох чуттєво-естетичних і сенсорних здібностей, що не лише впливає на загальну якість сприйняття, окрім того, цей процес набуває властивості замкнутого кола, адже відмирання творчих навичок збіднює інтелект, робить його діяльність механістичною, одновимірною, що неминуче призводить до зниження потенціалу мислення та деградації особистості.

Англійський учений Г. Осборн стверджує, що «художні враження підвищують жвавість розуму, інтенсифрікують досвід, насичуючи його глибиною особистого розуміння, адже розвивають і саму сферу почуттів. Зниження емоційного складника інтелекту позбавляє його творчої, спонтанної активності» [14, с. 318]. Істинна творчість не може бути породжена лише сухим розрахунком, автоматизмом раціональних операцій: для реалізації творчих можливостей необхідна жвавість розумових асоціацій, нестандартність логічних ходів, ініціативність уяви тощо.

У контексті соціального процесу, існують різноманітні, часто полярні за своєю сутністю концепції реалізації естетичного виховання дітей, одна з яких стверджує, що виховувати варто ті якості, в яких має потребу суспільство, адже якими б прекрасними не були ідеї про ідеальне естетичне виховання, вони мають дещо абстрактно-утопічний характер і можуть спричинити не лише різкий внутрішній конфлікт, а й неприйняття оточення. Функція виховання полягає в тому, щоб підготувати дитину до виконання тієї ролі, яку їй належить відігравати у суспільстві, тому система виховання прагне сформувати ії характер таким чином, щоб він наближався до соціально затребуваного. Однак у цьому випадку дитина, все більше стає буттям не цілісним, а функціональним як у сфері суспільного виробництва, так і сфері культурного вираження, починає характеризуватися домінуванням фрагментарного, неповноцінного сприйняття світу, інфантильного ставлення до нього.

Слід ураховувати, що такий уніфікований підхід не може задовольнити потреби всіх індивідів, а його наслідки в майбутньому здатні негативно вплинути на розвиток суспільства: з погляду сучасних вимог навіть позиція «старанного виконавця» стає все більш недостатньою, тому варто розвивати дитину як творчу особистість, що характеризується неординарністю мислення, оригінальністю у прийнятті рішень та самостійністю у судженнях. Адже саме творча позиція забезпечує дитині у майбутньому стійкість іїі існування, даючи можливість адекватно та своєчасно реагувати на всі нові ситуації мінливого світу, бути активним творцем, а не пасивним реципієнтом реальності.

Естетична теорія, спираючись на закони художнього життя мистецтва, переконливо доводить гармонізуючий вплив прекрасного на психічні структури особистості. Тут вбачається зумовленість їх зв'язку єдністю (але не тотожністю) етичної й естетичної форм суспільної практики. Інша річ, що для несформованої психіки, особливо у дитячому віці, соціальне середовище з позаморальними орієнтаціями може закласти стійке несприйняття краси і добра. Суспільство, що дбає про своє майбутнє, зобов'язане захистити молоді покоління від розчарування у красі, яка беззахисна перед злом. Інакше воно буде формувати циніків або байдужих людей, що само по собі створює безперспективність суспільства [8, с. 722].

У процесі естетичного виховання відбувається прилучення дітей до загальнолюдських цінностей, переведення їх із зовнішньої площини у внутрішній духовний зміст. На цій основі формується і розвивається здатність дитини до естетичного сприйняття та переживання, її естетичний смак й уявлення про ідеал. Виховання красою та завдяки красі формує естетико-ціннісну орієнтацію особистості, розвиває здатність дитини до творчості, створення естетичних цінностей у сфері трудової діяльності, повсякденному житті, вчинках і поведінці і, звичайно, у мистецтві.

Творчість - вільна діяльність, до якої дитину не можна примусити; вона може творити тільки через внутрішню потребу, внутрішнє спонукання до самореалізації, яке виступає більш дієвим чинником, ніж будь-який зовнішній тиск чи примус [4]. Лише творча поведінка в сучасному мінливому світі може вважатися справді адекватною, $є$ стимулюючим чинником у процесі еволюції: стаючи суб'єктом культури, дитина виявляється у всій повноті, багатогранності, неповторності своєї особистості, а розмаїття особистостей та багатство їх творчих здібностей забезпечує можливість перманентної адаптації до швидкозмінних реалій буття, стає запорукою розвитку суспільства як соціальної структури та духовного здоров'я людства.

\section{ВИСНОВКИ ТА ПЕРСПЕКТИВИ ПОДАЛЬШИХ ДОСЛІДЖЕНЬ}

Проблема естетичного виховання зростаючої особистості $\epsilon$ надзвичайно актуальною і необхідною для подальшого вивчення та наукового обґрунтування. Тільки естетично й морально багате покоління зможе 
розбудувати Україну як сильну державу та змінити стереотипи поведінки в сучасному суспільстві. Батьки, школа мають подбати про забезпечення всебічного розвитку особистості дитини на основі виявлення ії задатків і здібностей, виховати особистість з усталеними естетичними смаками, розвиненим почуттям прекрасного. Естетичне виховання залежить, по-перше, від соціуму й соціокультурного середовища, в якому перебуває дитина,

а по-друге, зумовлене психофізіологічним та загальнокультурним розвитком її особистісних якостей, здатностей і властивостей. Тобто естетичне виховання визначається природною обдарованістю, спонтанно формується в умовах сімейного, соціокультурного й освітнього середовища, детермінується життєвим і художньо-естетичним досвідом, актуалізується через цілеспрямований педагогічний вплив батьків, вихователів, учителів тощо.

Перспективним напрямом подальшого дослідження є поглиблене визначення системи, форм та методів естетичного виховання школярів, що відповідає сучасним концептуальним засадам реформування середньої школи в Україні.

\section{СПИСОК ВИКОРИСТАНИХ ДЖЕРЕЛ}

[1] Бутенко В. Г. Педагогіка краси як теоретико-методична основа естетичної освіти і виховання молоді. Педагогічна і психо-логічна науки в Україні : зб. наук. пр. : в 5 т.. Київ, 2007. Т. 1 : Теорія та історія педагогіки. С. 267-278.

[2] Выготский Л. С. Воображение и творчество в детском возрасте. 3-е изд. Санкт-Петербург: Питер, 2001. 93 с.

[3] Гончаренко С.У. Український педагогічний словник. Київ : Либідь, 1997. 376 с.

[4] Джола Д. Б., Щербо А. Б. Теорія і методика естетичного виховання школярів : навч.-метод. посіб. Київ : ІЗМН, 1998. 390 с.

[5] Зязюн І. А. Естетичне виховання - важливіший із складників загальнодержавної культурної політики. Рідна школа. 1994. № 1. C. $2-8$.

[6] Кудін В. О. Естетичне в системі навчання і виховання. Єдність раціонального та емоційно-почуттєвого в освітньо-виховних системах : наук.-метод. зб. Харків : ХДПУ, 1996. С. 12-14.

[7] Лихачев Д. С. Экология культуры. Избранные труды по русской и мировой культуре. Санкт-Петербург : Изд-во СПбГУП, 2006. С. 330-347.

[8] Мовчан В. Естетика: Історія і теорія. Жовква : Місіонер, 2010. 736 с.

[9] Отич О.М. Естетичний сенс індивідуальності. Мистецька освіта : зміст, технології, менеджмент : зб. наук. пр. Київ, 2008. Вип. 3. C. $40-52$.

[10] Сухомлинський В.О. Як виховати справжню людину? Вибрані твори: в 5 т. Київ : Рад. школа, 1976. Т. 1. 473 с.

[11] Brameld T. Patterns of Educational Philosophy: Divergence and Convergence in Culturological Perspective. New York : Holt, Rinehart and Winston, 1971. $415 \mathrm{p}$.

[12] Greene M. The Arts and National Standards. Educational Forum. New York : Teachers College, 1994. No. 58 (Summer). S. $391-400$.

[13] Lindberg A. Dilemma of art pedagogic - historic or modern strategy. Lund: Institusjonen för konstvetenskap, 2016.512 p.

[14] Osborne H. The art of appreciation. London : Oxford University Press. 1970. 498 p.

[15] The internet influence. URL : http://rankingtoday.com/articles/12/1/The-Internet-Influence.html.

\section{REFERENCES (TRANSLATED AND TRANSLITERATED)}

[1] Butenko V. H. Pedahohika krasy yak teoretyko-metodychna osnova estetychnoi osvity i vykhovannia molodi (Pedagogy of Beauty as a Theoretical and Methodological Basis of Aesthetic Education and Upbringing of Youth). Pedahohichna i psykholohichna nauky $v$ Ukraini : zb. nauk. pr. : $v 5$ t.. Kyiv, 2007. T. 1 : Teoriia ta istoriia pedahohiky. S. 267-278. (in Ukrainian)

[2] Vyhotskyi L. S. Voobrazhenye y tvorchestvo v detskom vozraste (Imagination and Creativity in Childhood). 3-e yzd. Sankt-Peterburh : Pyter, 2001. 93 s. (in Russian)

[3] Honcharenko S. U. Ukrainskyi pedahohichnyi slovnyk (Ukrainian Pedagogical Dictionary). Kyiv : Lybid, 1997. 376 s. (in Ukrainian)

[4] Dzhola D. B., Shcherbo A. B. Teoriia i metodyka estetychnoho vykhovannia shkoliariv (Theory and Method of Aesthetic Education of Schoolchildren). Kyiv : IZMN, 1998. 390 s. (in Ukrainian)

[5] Ziaziun I. A. Estetychne vykhovannia - vazhlyvishyi iz skladnykiv zahalnoderzhavnoi kulturnoi polityky (Aesthetic Education is One of the Most Important Components of Nation-Wide Cultural Policy). Ridna shkola. 1994. № 1. S. 2-8. (in Ukrainian)

[6] Kudin V. O. Estetychne v systemi navchannia i vykhovannia (Aesthetic in the System of Education and Upbringing). Kharkiv : KhDPU, 1996. S. 12-14. (in Ukrainian)

[7] Lykhachev D. S. Ekolohyia kultury (Ecology of Culture). Sankt-Peterburh : Yzd-vo SPbHUP, 2006. S. 330-347. (in Russian)

[8] Movchan V. Estetyka: Istoriia i teoriia (Aesthetics: History and Theory). Zhovkva : Misioner, 2010. 736 s. (in Ukrainian)

[9] Otych O.M. Estetychnyi sens indyvidualnosti (Aesthetic Sense of Individuality). Mystetska osvita : zmist, tekhnolohii, menedzhment : zb. nauk. pr. Kyiv, 2008. Vyp. 3. S. 40-52. (in Ukrainian)

[10] Sukhomlynskyi V.O. Yak vykhovaty spravzhniu liudynu? (How to Raise a Real Person?) Vybrani tvory: v 5 t. Kyiv : Rad. shkola, 1976. T. 1. $473 \mathrm{~s}$. (in Ukrainian)

[11] Brameld T. Patterns of Educational Philosophy: Divergence and Convergence in Culturological Perspective. New York : Holt, Rinehart and Winston, 1971. 415 p. (in English)

[12] Greene M. The Arts and National Standards. Educational Forum. New York : Teachers College, 1994. No. 58 (Summer). S. $391-400$. (in English)

[13] Lindberg A. Dilemma of art pedagogic - historic or modern strategy. Lund: Institusjonen för konstvetenskap, 2016. 512 p. (in English)

[14] Osborne H. The art of appreciation. London : Oxford University Press. 1970. 498 p. (in English)

[15] The internet influence. URL: http://rankingtoday.com/articles/12/1/The-Internet-Influence.html. (in English) 